\title{
S25
}

\section{Sequence Stratigraphy and Reservoir Characterization of the Uppermost Devonian- carboniferous in Southwest Algeria}

\author{
H. Abdallah* (Repsol YPF), J.M. Jauregui (Repsol YPF), S. Adrianto (Repsol \\ YPF), J. Gerard (Repsol YPF), F. Djettou (Sonatrach), R. Afrazmanech \\ (Repsol YPF), E. Figari (Repsol YPF), K. Nouar (Schlumberger) \& N. Ibrihen \\ (Repsol YPF)
}

\section{SUMMARY}

The Upper Devonian-Carboniferous reservoirs correspond to new hydrocarbon plays in south western Algeria, highlighted during the recent Repsol s exploration drilling campaign (2003-2007). Strunian and Tournaisian sandstone units produced potential gas flows from several wells essentially located in the western trend of Reggane basin. They correspond to prograding fluvial-deltaic cycles from South to North, alternating with transgressive events, prior to the global marine environment during the Upper Carboniferous. Tidal currents and storm action were the main processes which controlled sediment deposition.

Reservoir characterization is the main objective of this integrated study using chronostratigraphy and 3D modelling. Biostratigraphy and field work will complete the data base in this wide area. In terms of reservoir properties, main regional quality variations seem to be related to facies changes and diagenesis effects. 
This work presents a geological model for the Carboniferous in the Reggane basin, located southwest of Algeria. This period is characterized by several but subtle intra-Carboniferous unconformities, and by a strong compressive tectonics event during the Hercynian phase (end Stephanian), which generated the key tectonic elements of Reggane basin.

The Strunian sequence De-6 (upper Devonian) represents a regressive episode recognisable across much of North Africa (fluvial-deltaic progradation) terminated by a regional transgression. The upper part consists of three smaller scale prograding cycles. The main sediment supply direction was from SE to NW with some variations related to the presence of local active highs.

During Tournaisian $(\mathrm{Cb}-\mathrm{I})$, the two uppermost correlative small scale prograding cycles were followed by a regional transgressive event. Sedimentation was dominated by sub-tidal currents and storm action locally reworking and cleaning the sediments.

Visean (Cb-II) in Reggane basin was deposited in marginal marine and fluvial environments, mainly in regressive cycles, with local sediment-supply from West and East, followed by a regional transgressive event. The upper part of Visean consists of carbonates, deposited on a marine platform, followed by a restricted environment where some evaporites were deposited.

The Upper Carboniferous or Namurian sediments (Cb-III) in Reggane basin are largely composed of sands and shales with evaporitic facies, including anhydrites and occasional limestones, highlighting this important regressive cycle.

The geological model built in Reggane basin covered an area of $73 \mathrm{~km}$ by $167 \mathrm{~km}$ following the classical workflow: seismic interpretation, geology, petrophysics and geocellular modelling in Petrel. The seismic interpretation is based on 3D plus several 2D seismic profiles, but no special seismic attribute work was performed. The geological studies (sedimentology) were mostly based on the well core descriptions, carried out in the two major reservoirs: Tournaisian \& Strunian, which are the main gas targets. Log responses and petrophysical properties were correlated and integrated with sedimentological facies in order to determine lithotypes or electrofacies (massive sand, laminated sand and shale background). Detailed correlation was based upon high resolution sequence analysis. A broad layering was also defined using the main electrofacies variations, confirming the subdivision of the Tournaisian \& Strunian section. The regional sand source for the Strunian and Tournaisian sections is classically believed to be from the South (Eglab Massif). In contrast, the evidence of this study suggests a possible local-sourcing from both East and West, although this remains to be confirmed with the new data. Tournaisian \& Strunian sediments are characterized by repetitive coarsening-upward cycles, thinning towards the North West. Both tidal currents and storms controlled sediments deposition within the following major environments:

1) Channelized upper shoreface 2) Upper Shoreface 3) Lower Shoreface 4) Offshore shelf. The "Tournaisian \& Strunian" are characterized by sand bodies with internal permeability anomalies linked to facies changes, although these are difficult to evaluate, due to diagenetic alterations and the relatively limited amount of core material.

A detailed field sedimentology work which will be performed shortly south of Reggane basin, in Ain Chebbi and Hassi Taibine areas, will be integrated to this study. The main target will be to fit the basin model to the outcrops in order to identify the main chronostratigraphic surfaces and eventually adjust the paleo current directions to better know the sediment source for the different reservoirs.

Integrating all these valuable elements in the study will put more confidence in the upper Devonian and Lower Carboniferous 3D modelling. 